\title{
The DNA-instability test as a specific marker of malignancy and its application to detect cancer clones in borderline malignancy
}

\author{
M. Fukuda, A. Sun \\ Department of Oncological Pathology, Faculty of Medicine, University of Fukui, Matsuoka, Yoshida-Gun, \\ Fukui, Japan
}

(C)2005, European Journal of Histochemistry

Recent progress in cytogenetic and biochemical mutator assay technologies has enabled us to detect single gene alterations and gross chromosomal rearrangements, and it became clear that all cancer cells are genetically unstable. In order to detect the genome-wide instability of cancer cells, a new simple method, the DNA-instability test, was developed. The methods to detect genomic instability so far reported have only demonstrated the presence of qualitative and quantitative alterations in certain specific genomic loci. In contrast to these commonly used methods to reveal the genomic instability at certain specific DNA regions, the newly introduced DNA-instability test revealed the presence of physical DNA-instability in the entire DNA molecule of a cancer cell nucleus as revealed by increased liability to denature upon $\mathrm{HCl}$ hydrolysis or formamide exposure. When this test was applied to borderline malignancies, cancer clones were detected in all cases at an early-stage of cancer progression. We proposed a new concept of "procancer" clones to define those cancer clones with "functional atypia" showing positivities for various cancer markers, as well as DNA-instability testing, but showing no remarkable ordinary "morphological atypia" which is commonly used as the basis of histopathological diagnosis of malignancy.

Key words: Atherosclerosis; stable angina; acute coronary syndromes without ST elevation; gene expression; 5' nuclease (TaqMan ${ }^{\mathrm{TM}}$ ) assay; eNOS; immunohistochemistry

Correspondence: Prof. Masaru Fukuda, MD,

Department of Oncological Pathology,

Faculty of Medicine, Matsuoka, Yoshida-Gun,

9I0-II93, Fukui, Japan

Tel +81.776 .278020$

Fax: +81.776.279717

E-mail: mitamu_m@sec.icpc.fukui-u.ac.jp

Paper accepted on December 3, 2004

European Journal of Histochemistry

2005; vol. 49 issue 1 (Jan-Mar):???-???

\section{Genomic instability}

It is now widely accepted that cancer may be genetically unstable (Lengauer et al., 1998), and that the genomic instability is the engine of both tumor progression and heterogeneity (Nowell, 1976; Shen et al., 2000). The tumor instability is defined by a more rapid accumulation of genetic alterations in tumors compared with normal cells, and is classified into four different types, (1) subtle sequence changes; (2) alterations of chromosome numbers; (3) chromosome translocations; and (4) gene amplifications (Lengauer et al., 1998).

\section{Subtle sequence changes}

These changes involve base substitutions, deletions, and insertions of a few nucleotides. The repair machinery operates on sequence errors generated by polymerases or by mutagens.

\section{Translesion bypass}

Recently, a large number of new DNA polymerases have been identified, which although sharing significant amino acid sequence identity and similarity amongst themselves, exhibit little homology to any of the five previously identified polymerase families (Cordonnier and Fuchs, 1999; Frieberg and Gerlach, 1999; Johnson et al., 1999; Woodgate, 1999) and is referred to as the Y-family of DNA polymerases (Ohmori et al., 2001). Among them, the xeroderma pigmentosum variant (XPV) gene encodes human DNA polymerase $\eta$, (poly $\eta$ ), which catalyzes efficient and accurate translesion synthesis past cis-syn-cyclobutane di-thymine lesions produced by ultraviolet light irradiation, not only by incorporating the correct nucleotide opposite a lesion, but also by elongating DNA chains that have a correctly incorporated nucleotide opposite a lesion (Masutani et al., 1999, 2000). Although these new DNA polymerases preferentially incorporate $\mathrm{dCMP}$ opposite acetylaminofluorene (AFF)-G 
and cysplatin-GG, other nucleotides are also incorporated opposite these lesions (Masutani et al., 2000).These mispaired incorporations of nucleotides or genomic alterations by poly $\eta$ with its replacement by more error-prone bypass DNA polymerases may further cause a serious threat to genomic stability.

\section{Nucleotide-excision repair}

Nucleotide-excision repair (NER) genes are responsible for repairing damage caused by many exogenous mutagens, and skin tumors represent the major tumor type to which patients with NER defects are susceptible. In a heterozygote with one defective NER allele, however, inactivation of the normal allele does not always lead to a high mutation rate, because exposure to an additional environmental agent, ultraviolet light, is required to engender such mutations (Lengauer et al., 1998).

\section{Mismatch repair ( $M M R$ )}

A subset of sporadic colorectal cancers and most hereditary nonpolyposis colorectal cancer patients display frequent alterations in microsatellite sequences, (CA)n repeats, showing replication errors $\left(R E R^{+}\right)$or microsatellite instability (MIN or MMR-) (Parson et al., 1993: Lengauer et al., 1998). Elements of microsatellites constitute one of the most abundant classes of repetitive DNA families in humans, and 50,000 to 100,000 (CA)n repeats are scattered throughout the human genome and may exhibit length polymorphisms (Thibodeau et al., 1993). Six human mismatch repair genes are now known which, when inactivated by mutation, lead to a MIN phenotype in cancer patients (Peltomaki and Chapelle, 1997). The tandem nature of elemental units within simple repeats is thought to render such sequences prone to slippedstrand mispairing and hence particularly prone to insertion or deletion mutagenesis during replication (Levinson and Gutman, 1987; Kunkel, 1993). Centromeres, which are essential chromosome structures for correct segregation of sister chromatids, are large, in the range of megabases, often containing repetitive DNA sequences in the condensed heterochromatin (Choo, 200l; Schueler et al., 2001; Goshima et al., 2003). Obuse et al. (2004) identified 40 genes including oncogenes in the interphase centromere complex (I-CEN-complex) which contains all proteins constituting centromeres and centromere chromatin. MIN introduced in centromeres, therefore, may induce defected checkpoint machinery for cell proliferation and differentiation.

\section{DNA methylation}

Cytosine-5-methyltransferase catalyzes the transfer of a methyl group from S-adenosylmethionine to the C5 position of cytosine (Santi et al., 1983). Abnormal methylations are very common in cancer cells and are capable of directly modifying carcinogenesis, causing point mutations in tumor suppressor genes in somatic and germ line cells (Jones, 1996). Hypomethylation preferentially occurs in DNA repeats contained in Alu and alpha-satellite and induces abnormalities of cell cycle checkpoints and genomic instability by alterations of the related genes (Cahill et al., 1994, 1998; Wong et al., 1999; Ferguson et al., 2000; Kikuchi et al., 2002; Satoh et al., 2003; Toyota et al., 2003).

\section{Alterations in chromosome number}

Chromosome number instability (CIN) involving gains and losses of whole chromosomes, aneuploidy, are likely to occur in most human malignancies (Mitelman et al., 1994; 1997). As reviewed by Lengauer et al. (1998) in detail, genes that, when mutated, can lead to CIN include those involved in chromosome condensation, sister-chromatid cohesion, kinetochore structure and function and centrosome-microtube formation, as well as checkpoint genes that monitor the proper progression of the cell cycle (Hartwell and Smith, 1985; Hartwell, 1992; Murray, 1995; Ellege, 1996; Fukasawa et al., 1996; Nasmyth, 1996; Paulovich et al., 1997; Taylor and Mckeon, 1997; Doxsey, 1998; Jin et al., 1998; Lane, 1998; Rotman and Shiloh, 1998; Zhang et al., 1998). The fact that genetic defects of so many genes can lead to CIN suggests a heterogeneous basis for CIN in cancers, with many genes each playing a role in a small proportion of the cases (Lengauer et al., 1998). In DNA-damage checkpoint deficiency, chromosomes containing damaged DNA could segregate inappropriately, resulting in CIN because sister chromatids are still connected by DNA or DNA-protein links and are also susceptible to gross structural alterations due to single-stranded gaps or double-stranded breaks. Genomic deletion caused by double-stranded breaks is reflected in the genomic mechanism of loss of heterozygosity $(\mathrm{LOH})$, and losses of maternal or paternal alleles.n a tumor are widespread and are often accompanied by a gain of the opposite allele (Lengauer et al., 1998; Shen et al., 2000). 
Chromosome instability arising from failed DNAdamage checkpoints is often associated with enhanced mitotic recombination as well as with aberrant chromosome segregation (Hartwell and Smith, 1985). Thus, cancer progression is often associated with the accumulation of these gross chromosomal rearrangements (GCRs), such as translocations, deletions of chromosome arms, interstitial deletions or inversions (Gauwerky and Croce, 1993; Shikano et al., 1993; Mitelman, 1997; Chen and Kolodner, 1999). In many instances, GCRs inactivate tumor-suppressor genes or generate novel fusion protein that initiate carcinogenesis (Gauwerky and Croce, 1993; Barr, 1998). As described above, methylation deficiency $\left(\mathrm{MET}^{-}\right)$often induces many genomic alterations and may finally form CIN. Jones and Gonzalgo (1997) suggested the existence of two different phenotypes of MMR(MIN)-MET', and MMR+$M E T$, and this will explain an inverse relationship between CIN and MIN in colorectal and endometrial cancers (Lengauer et al., 1998). Cancers showing MMR deficiency are generally diploid, whereas M M R-proficient tumors are usually aneuploid showing CIN.

\section{Chromosome translocations}

These alterations can be detected cytogenetically as fusions of different chromosomes or of normally non-contiguous segments of single chromosomes. At the molecular level, such translocations give rise to fusions between two different genes, encoding fused transcript with tumorigenic properties (Lengauer et al., 1998). Large portions of chromosomal arms are often deleted during recombination that lead to translocations, and these deletions are seen as the losses of heterozygosity at the molecular level. Translocations will arise in cells that enter mitosis before recombination-promoting doublestranded DNA breaks are repaired. Alterations of genes involved in double-stranded breaks or DNAdamage checkpoints therefore, will induce the translocation instability in human cancers (Lengauer et al., 1998).

\section{Gene amplification}

Gene amplifications are seen at the cytogenetic level as homogeneously stained regions or double minutes. At the molecular level, multiple copies of an amplicon containing growth promoter genes can be seen (Lengauer et al., 1998). The mechanisms through which amplifications are generated are largely unknown, but amplifications occur more easily when p53 is inactivated (Yin et al., 1992).

\section{DNA-instability test}

As described above, recent progress in cytogenetic and biochemical mutator assay systems has enabled us to detect single gene alterations and gross chromosomal rearrangements (GCRs), from which it became clear that all cancers are genetically unstable. In order to detect the genome-wide instability of cancer cells, we developed a new method, the DNA-instability test.

\section{Background}

By quantitative analysis of the Feulgen hydrolysis curve, it was found that the extent to which nuclear DNA exposed to acid is denatured reflects the degree of DNA instability, which depends on the chromatin structure (Darzynkiewicz et al., 1979; Fukuda et al., 1985, 1986). The Bateman function was found to be appropriate for the Feulgen hydrolysis curve analysis (Böhm and Seibert, 1966; Pöppe et al., 1979; Madokoro et al., 1985). According to the Bateman function, the amount of apurinic acid or single-stranded DNA present at hydrolysis time $t$, is expressed by the equation $y(t)=y_{0} k_{1} /\left(k_{2}-k_{1}\right) *\left(e^{-k 1 t}-e^{-k 2 t}\right)$, and the amount of apurinic acid or single-stranded DNA potentially present initially $\left(\mathrm{y}_{0}\right)$, as well as the rate constants for its production $\left(k_{1}\right)$ and degradation $\left(k_{2}\right)$, can be determined by fitting the function to the experimentally obtained hydrolysis curve. The hydrolysis curve is influenced by a number of factors, including the kinetics of the hydrolysis reaction and chromatin structure. In chicken erythrocytes, for instance, it was found that the depurination rate constant is decreased in compact form of chromatin (Duijndam and van Duijn, 1975). We also analyzed acridine orange $(\mathrm{A} O)$ hydrolysis curves obtained for various normal cell types, various cancer cell types, damaged cells induced by the administration of chemical carcinogens or X-ray irradiation, and neuronal cells in the process of aging, and it was found that the value of $1 / k_{1}$ reflects the degree of chromatin condensation, while the values for $y_{0}$ and $k_{2}$ correlate with the degree of DNA instability or DNA damage (Fukuda et al., 1985; Miyoshi et al., 1986). It was found that the $k_{2}$ value, which reflects the degree of DNA instability, is much larger for 
cancer cells than for normal cells (Fukuda et al., 1986). This finding led us to develop a method for differential fluorescent $\mathrm{AO}$ staining of cancer cells and non-cancerous cells utilizing the different degree of DNA instability at acid hydrolysis. The fluorochrome bound to the single-stranded polynucleotide, apurinic acid, emits metachromatic red-shifted fluorescence due to dye aggregation, while that intercalated in the intact double-stranded polynucleotide emits orthochromatic green fluorescence (Darzynkiewicz et al., 1979).

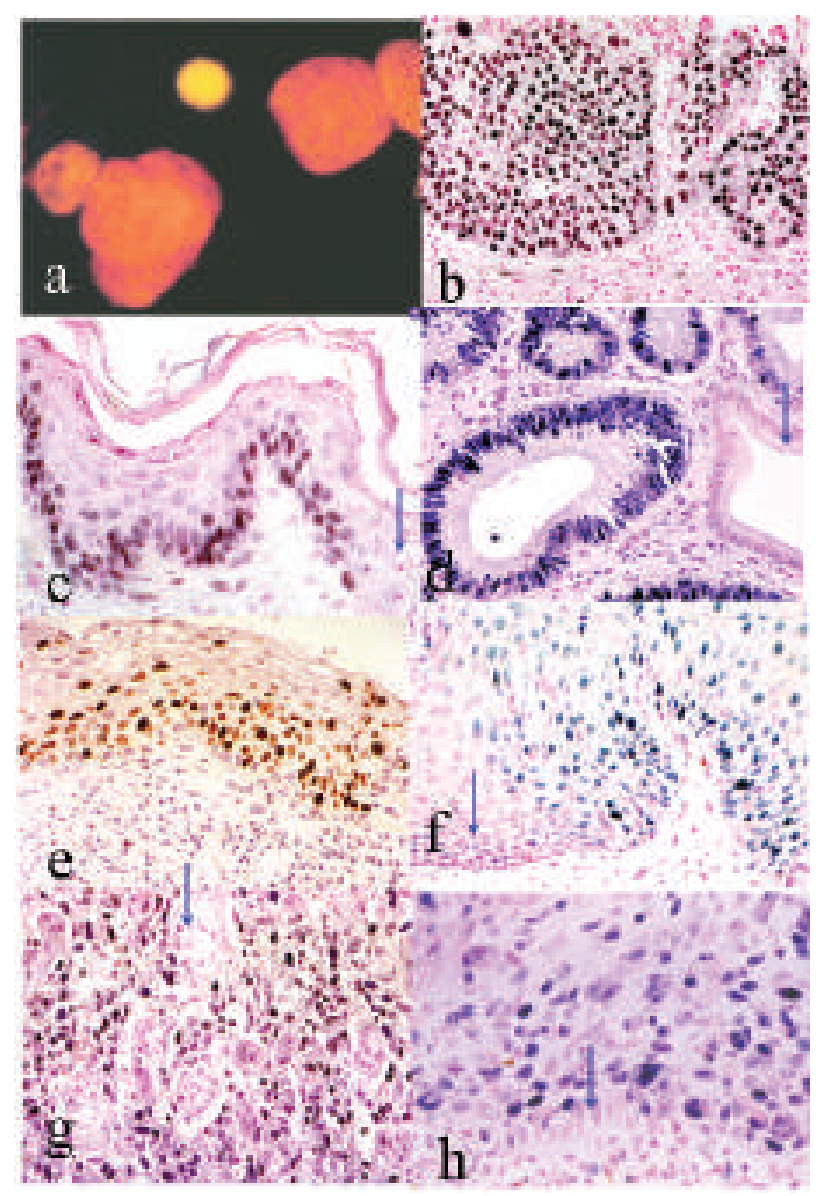

Figure 1. The DNA-instability test by fluorescent AO staining (a), and immunohistochemical staining with anti-cytidine antiserum (b-h), after HCl hydrolysis. a; smear specimen of uterine cervical cancer. One lymphocyte included emits orthochromatic yellow-green fluorescence. b; urinary bladder cancer, papillary non-invasive TCC, GI. c; hyperplastic mouse epidermis induced by 20-MC. Procancer cells (positive) and normal epidermal cells (arrow). d; gastric tubular adenoma, moderate dysplasia, with one negative gland (arrow). e; uterine cervical mild dysplasia showing the presence of procancer cells (DAB-positive). $f$; oral leukoplakia showing moderate dysplasia containing procancer cells at the border of normal mucosa (arrow). Normal mucosa is indicated by an arrow. g; bone giant cell tumor showing diffusely positive stromal cells and negative multinucleated giant cells (arrow). h; preserved basal cells (arrow) in Bowen's disease.

\section{Differential acridine orange-fluorescent staining specific for cancer cells}

AO staining after hydrolysis with $2 \mathrm{~N} \mathrm{HCl}$ at $30^{\circ}$ C for 8.5 min was found to be the optimal condition (Fukuda et al., 1986). In human malignant tumors of epithelial and nonepithelial origin tested, all malignant tumor cells emitted metachromatic red fluorescence, while all of the non-malignant tumor cells and normal cells emitted orthochromatic green fluorescence when observed with a violet excitation light under a fluorescence microscopy (Figure 1a).

\section{Differential immunohistochemical staining specif- ic for cancer cells using anti-single-stranded DNA antiserum}

The above described fluorescent AO staining for specific differentiation of cancer cells was also applied to the ordinary paraffin-embedded sections, but no differential fluorescent staining was obtained: possibly due to delicate alterations of nuclear DNA by the procedures of specimen preparation, and at present, this method is applicable only to the smeared specimens of isolated cells. Then, an improved method by using anti-singlestranded DNA antiserum which could bind more specifically to single-stranded nucleotide induced by acid hydrolysis was developed (Fukuda et al., 1993). The ordinary pathological sections were immunohistochemically stained with the antiserum after RNase digestion and DNA denaturation by hydrolysis with $2 \mathrm{~N} \mathrm{HCl}$ at $30^{\circ} \mathrm{C}$ for 20-30 min, and all cancer cells were specifically stained positive, in sharp contrast to the negative stainability of all non-cancerous cells (Figure Ib).

\section{Differential in situ-hybridization (ISH) method specific for cancer cells}

As for anti-single-stranded DNA antiserum, polyclonal anti-single-stranded DNA antiserum and monoclonal anti-cytidine antiserum were used in the immunohistochemical DNA-instability test described above. When the fixation of specimen was not appropriate, too long or insufficient, even noncancerous cells sometimes showed weak but positive staining. Inappropriate fixation could induce partial denaturation of nuclear DNA which will render even non-cancerous cell nuclei positive for the immunohsitochemical staining with anti-singlestranded DNA antiserum. In order to overcome this problem, an ISH method using a larger molecule as 
a probe was developed, which bound more specifically to just sufficiently denatured DNA induced by the treatment with formamide solution (unpublished). The outline of this method is as follows:

(a) genomic DNA was extracted from frozen human liver stored at autopsy by homogenization and cell lysis, followed by RNase digestion and protein extraction;

(b) then the DNA was labeled with biotin by nick translation forming 500-2,000 kbp DNA fragments, followed by reaction with the avidin-biotin peroxidase complex;

(c) ordinary pathological sections and ethanolfixed smeared specimens of isolated cells were treated with proteinase $\mathrm{K}$, followed by the treatment with $70 \%$ formamide solution at $60^{\circ} \mathrm{C}$, for 10 min or 50-60 min, respectively. Then the specimens were bound with the DNA probe, followed by the color reaction with $\mathrm{DAB}$ or $\mathrm{Co}-\mathrm{DAB}$ to visualize the peroxidase reaction. By this method, the specificity for cancer cells was fairly improved even in inappropriately fixed specimens. When acid hydrolysis was used to denature nuclear DNA, even cancer cells apparently identified morphologically sometimes showed pseudo-negative stainability, presumably because of DNA-loss; and non-cancerous cells also sometimes stained positive, possibly due to partial denaturation of nuclear DNA artificially induced by inappropriate fixation. DNA denaturation with formamide solution, on the other hand, may not evoke DNA-loss because it is much milder than $\mathrm{HCl}$ hydrolysis. Furthermore, a DNA probe of large molecular weight will not bind to partially denatured nuclear DNA as artificially induced by inappropriate fixation. Since the first report of the DNA-instability test (Fukuda et al., 1986), numerous malignancy cases and so-called borderline malignancy cases were examined by this method, and all cancer cells were found to be positively stained, while comparative normal cells including vascular endothelial cells, fibroblasts and inflammatory cells contained in the same specimen were all completely negative. As described in this paper, a great number of reports concerning genomic instability of cancer cells have been presented. These reports, however, only demonstrated the presence of qualitative and quantitative alterations in certain specific genomic loci. In contrast to these commonly used methods to reveal genomic instability of cancer cells at certain specific DNA regions, the DNA-instability test above introduced revealed the presence of physical DNA instability in the entire DNA molecule of a cancer cell nucleus as demonstrated by increased liability to denature upon $\mathrm{HCl}$ hydrolysis or treatment with formamide solution. The mechanism of increased physical DNA instability of cancer cells against acid hydrolysis or treatment with formamide is not fully understood, but possible mechanisms have been proposed (Hatchoh et al., 1992; Fukuda et al., 1993; Nitta et al., 1993; Otaki et al., 1994). In addition to a variety of accumulated genomic alterations in cancer cell DNA, disturbed function of histone production due to certain genomic damage will impair the DNA packing function and may result in abnormal configuration that will also induce increased DNA instability upon $\mathrm{HCl}$ hydrolysis or treatment with formamide. Another possible mechanism of increased physical DNA instability of malignancy may be attributable to the production of reactive oxygen by cancer cells (Noriki et al, 1989; Fukuda et al., 1993). In the cell membrane of cancer cells, the amount of unsaturated fatty acids is known to be increased (Wood et al., 1985) with increased lipid peroxide (Noriki et al., 1989; Otamiri and Sjodhal, 1989), because unsaturated fatty acids are susceptible to peroxidation to produce lipid peroxide. The latter is included in the group of reactive oxygen, and may be the source of radical chain reactions producing further reactive oxygen. Reactive oxygen modifies enzymatic and structural proteins, rendering them susceptible to proteolytic attack (Levine et al., 198I; Dean, 1987), and gives rise to membrane damage through lipid peroxidation. This harmful chain reaction induces the inactivation of the enzymes which act as reactive oxygen scavengers. These finally induce serious DNA damage by modification, strand-break, and oxidative degeneration (van Hemmen and Meuling, 1975; Kasai and Nishimura, 1986; Peskin and Shlyanova, 1986; Noriki et al., 1989).

\section{Applications of the DNA-instability test to detect cancer clones in borderline malignancy}

\section{Clonal evolution and progression of 20-methyl- cholanthrene-induced squamous cell carcinoma in mouse epidermis (Hirai et al., 2001)}

In an attempt to understand the dynamic process of carcinogenesis and cancer progression, the clonal evolutions of squamous cell carcinoma (SCC) were examined in the lesions induced by repeated 
topical applications of 20-methylcholanthrene (20$\mathrm{MC}$ ) to the mouse skin, which induces hyperplastic epidermis, papillomatous lesion and invasive carcinoma. The lesions were examined histopatholigically and immunohisto-chemically using anti-singlestranded DNA antiserum after $\mathrm{HCl}$ hydrolysis (DNA-instability test). Multiple clones with increased DNA instability at acid hydrolysis comparable to that of invasive carcinoma were noted already in early-stage (2-6 weeks) hyperplastic epidermis, and their number increased in middle (7-II weeks), and late-stage (12-25 weeks) of hyperplastic epidermis showing clonal expansion, indicating that they belong to malignancy category (Figure 1c). All papillomatous lesions and invasive carcinomas showed positivity to the DNA-instability test. The analyses were carried out on the same lesions by means of the immunohistochemical labeling of p53 (a gene producing a protein which inhibits the entrance of abnormal cells to S-phase through $G_{1}$ $S$ checkpoint and push those to apoptosis even after slipping into S-phase: Finlay et al., 1988; Hollstein et al., 1991), of VEGF (vascular endothelial growth factor, a protein which induces vascular endothelial cell proliferation: Leung et al., 1989), of DFF45 (a protein which inhibits DNA fragmentation at the final step of apoptosis by forming dimer with DFF40, a DNase: Liu et al., 1997; Enari et al., 1998; Sabol et al., 1998; Sasaki et al., 1999), of PCNA (proliferating cell nuclear antigen, an auxiliary protein for DNA polymerase $\delta$, playing an important role in the initiation of cell proliferation: Bravo et al., 1987; Wong et al., 1987; Jaskulski et al., 1988; Yang et al., 1993), and by staining AgNORs (chromosomal regions where genes for major ribosomal RNA are located, of which number may reflect the capability of cell proliferation and the degree of neoplastic malignancy: Goodpasture and Bloom, 1975; Howell et al., 1975; Reeves et al., 1984; Arden et al., 1985; Crocker et al., 1987; Ayres et al., 1988; Dervan et al., 1989; Muscare et al., 1991; Yu et al., 1992). Cells with positive immunostaining for these cancer markers and with abnormal AgNORs parameters appeared (although with different percent values) in the clones with positive DNA-instability test in early- or middle-stage hyperplastic epidermis; and increased markedly in number in keeping pace with the clonal expansion in late-stage hyperplastic epidermis, papillomatous lesions and invasive carcinomas. The percentage of PCNA-positive vascular endothelial cells was significantly higher under the VEGF-positive clones showing positive DNA-instability test, and became higher toward the late-stage of cancer progression. Although the PCNA-positive cells were well defined in the basal layer in normal epidermis, the normal distribution was more or less disturbed already in the early- or middle-stage hyperplastic epidermis, especially in the clones with positive DNA-instability test, and markedly disturbed in the late-stage of hyperplastic epidermis, papillomatous lesions and invasive carcinomas. This clearly indicates the presence of disturbed cell proliferation and differentiation in these lesions, reflecting again the malignant characteristics. Although the foci with positive DNA-instability test were also often positive for these cancer markers, it was almost impossible to identify them as malignant based upon simple morphological criteria, because the degree of cellular and structural atypia in these foci was not highly pronounced, although the nuclei and nucleoli were only slightly enlarged even in the late-stage hyperplastic epidermis and papillomatous lesions. Based on these findings, we proposed a new concept of procancer (not pre-cancer as commonly used) as a cancer clone at an early-stage of cancer progression. A procancer clone already exhibits increased physical DNA instability as revealed by positive DNA-instability test with positivities for various cancer markers such as p53, VEGF, DFF45, PCNA and abnormal AgNORs parameters, but without remarkable morphological atypia to be used as the basis of malignancy diagnosis. We also defined these phenotypic abnormalities as functional atypia opposed to commonly used morphological atypia (Figure 2). We interpreted the dynamics of carcinogenesis and cancer progression demonstrated in this study as follows: procancer clones with positive DNA-instabili-

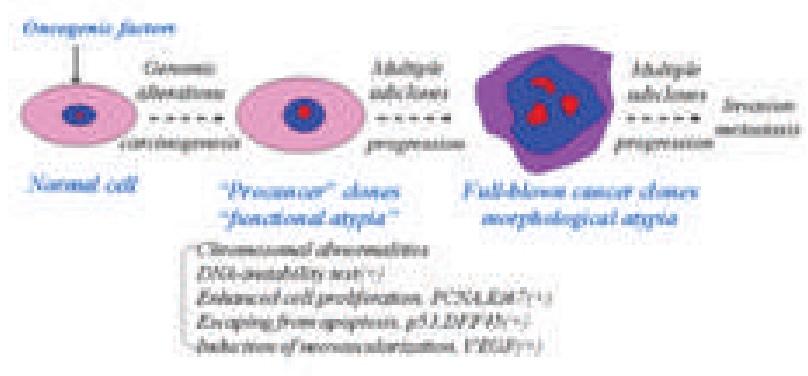

Figure 2: The concept of "procancer" clones showing "functional atypia". 
ty test appeared within 2 weeks after commencing topical applications of 20-MC. The number of these clones increased continuously toward the middleand late-stage hyperplastic epidermis showing positivities for various cancer markers, reflecting clonal expansion. The number of papillomatous lesions derived from the procancer clones is much smaller than that of the latter. Furthermore, all cancer lesions identified by enhanced degree of morphologicl atypia appeared only in the preceding papillomatous lesions, but they did not appear directly in the hyperplastic epidermis. The term papilloma seems to be inappropriate and should be replaced by papillomatous lesion, because all papillomatous lesions were positive for DNA-instability test and other cancer markers, indicating that all cells in the lesion are regarded already as cancer cells, and they must be referred to as procancer. The procancer clones with high DNA instability would produce multiple cancer sub-clones by enhanced proliferative activity as revealed by increased PCNApositivity. Mutations of the p53 gene would also enhance proliferation and reduce the likelihood of apoptotic cell death of procancer clones. Furthermore, paracrine secretion of VEGF by procancer clones in hyperplastic epidermis would induce dermal neovascularization, which in turn would enhance the growth and transition of flat hyperplastic epidermis to papillomatously elevated lesion by providing sufficient levels of oxygen and nutrients. A high percentage of DFF45-positive cells, especially in the late-stage of hyperplastic epidermis, papillomatous lesions and invasive carcinomas, could be interpreted as induction. The induced DFF45 binds to DFF40 and blocks its DNase activity, thereby allowing cancer cells to avoid the DNAfragmentation machinery immediately before the final step of apoptosis. Taken together, these new features adopted by procancer and cancer clones should favor an increase in the number of descendants which could accept abundant nutrients, having a high chance to survive by escaping the apoptotic machineries driven by $p 53$ and DFF40. Consequently, multiple cancer clones showing cancer progressions which would be suitable to invade or metastasize may be produced.

\section{Detection of procancer clones in human gastric adenoma (Otaki et al., 1994; Sun et al., 2003)}

Gastric adenoma is defined by the World Health Organization (WHO) as circumscribed benign lesions, composed of tubular and/or villous structures showing intra-epithelial neoplasia (FenoglioPresiser et al., 2000), and is widely considered to be a pre-malignant lesion (Correa et al., 1992). According to the degree of cellular and structural dysplasia, gastric adenoma is divided into two qualitative grades (low-grade and high-grade dysplasia) or three qualitative grades (mild, moderate and severe dysplasia) (Ming et al., 1984; Tosi et al., 11989: Goldstein and Lewin, 1997). Many authors have investigated the relationship between gastric adenoma and cancer, and showed that the frequency of malignant transformation from adenoma to carcinoma depends on size and histological grade of adenoma (Nakamura et al., 1988; Xuan et al., 1991; Tsujitani et al., 1992). Most investigators agree that severe, or high-grade dysplasia is the most important precursor of gastric cancer and strongly recommend gastrectomy, endoscopic mucosal resection (EMR) or polypectomy, particularly in light of the high percentage of early gastric cancer (Lansdown et al., 1990; Farinati et al., 1991; Di Gregorio et al., 1993). However, there remains disagreement regarding the risk of malignant potential for adenomas with mild and/or moderate dysplasia. Some authors believe that adenomas with mild and moderate dysplasia progress slowly or regress (Saraga et al., 1987; Farinati et al., 1989), while others have reported that the progression to severe dysplasia or evolution into gastric carcinoma ranged between $19-21 \%$ and $33-$ $40 \%$ in mild and moderate dysplasia, respectively (Rugge et al., 1991; Feritta et al., 1993; Rugge et al., 1994). The morphological criteria for evaluating the potential malignancy, or probability of transition to overt cancer of gastric adenoma, however, are quite ambiguous and controversial, and the validity of them is confusing in everyday diagnosis. The DNA-instability test was applied to bioptic tissues of human gastric polyp assessed histopathologically as foveolar hyperplastic polyp, mild, moderate and severe dysplasia adenoma, and carcinoma lesions. The serial sections of the same tissues were also subjected to immunohistochemical staining for Ki67 (Schlüter et al., 1993), p53, DFF45, and bFGF (basic fibroblast growth factor, a protein which has a similar effect as VEGF) (Folkman and Klagsbrun, 1987; Russel, 1989). The DNA-instability test was positive in 100\% adenocarcinoma cases and $100 \%$ severe dysplasia cases, indicating their malignancy. All foveolar hyperplastic polyps were 
negative to the DNA-instability testing. Furthermore, the percentage of glands positive for the DNA-instability test steadily increased in going from mild $(10 \%)$, to moderate $(40 \%)$, and to severe $(100 \%)$ dysplasia (Figure 1d). All other cancer markers examined showed significantly higher values in the adenoma glands, being positive for DNA-instability testing, irrespective of the dysplasia grade as compared to those in the adenoma glands that were negative for DNA-instability testing. Furthermore, the former values were comparable to those in adenocarcinoma, indicating no difference of the values between adenoma and cancer in the areas with positive DNA-instability test. These results indicate that cancer cell clones are already present at the adenoma stage showing a positive DNA-instability test, enhanced proliferative activity, p53 mutation, and induction of DFF45 and bFGF. These factors, as above described, again allow cancer cell proliferation, producing heterogeneous subclones due to DNA instability, enhancing their survival rates by escaping apoptosis, and providing abundant nutrients during the early-stage of progression of gastric cancer. These cancer clones in the early-stage of cancer progression can be also referred to asprocancer clones, as above described. While morphological criteria and existence of invasion seem to be the most reliable basis for malignancy diagnosis, it appears that a certain period is required before the degree of morphological atypia is manifested histopathologically to allow diagnosis of malignancy, even after the formation of procancer clones. During the extremely long incipient (1-4 years) and early (14-21 years) phases of tumor growth of gastric cancer (Fujita et al., 1978), the DNA alterations induced in cancer cells, which should be minute initially, will become intensified and exaggerated by repeated cell divisions (Hatchoh et al., 1992) during these long phases so as to make the diagnosis of cancer by the pathologist possible based upon the degree of morphological atypia. Further progression of procancer clones will produce the multiple subclones with the potency to invade and metastasize. Reflecting the malignant character of the procancer clones in adenomas, abnormal mitoses were encountered exclusively in those glands showing a positive DNA-instability test, indicating the presence of chromosomal abnormalities evoked by DNA instability (Steinbeck, 2001). Comparable results were also obtained in human colorectal adenoma (Nitta et al., 1993).

\section{Detection of procancer clones in uterine cervical dysplasia (Khaled et al., 2000)}

It is regarded that the majority of human uterine cervical carcinomas may arise through some premalignant changes, and that these changes are considered to have a greater or lesser degree of malignant potential. To present these stages as the spectrum of one single disease, it was initially introduced the concept of dysplasia/carcinoma in situ system, and later of CIN (cervical intra-epithelial neoplasia). The degree of potential malignancy, or the probability of transition to overt cancer of CIN is classified into 3 groups; CIN-I (mild dysplasia), CIN-2 (moderate dysplasia), and CIN-3(severe dysplasia) according to the cellular differentiation, nuclear abnormalities and mitotic activity in different layers of the mucosa. But the morphological criteria are quite ambiguous and controversial, and the validity of them is confusing in everyday diagnosis. The DNA-instability test was applied to mild, moderate, and severe dysplasia cases, squamous cell carcinoma in situ (CIS), invasive squamous cell carcinoma (SCC) cases, and normal human uterine cervix cases. The results showed that $100 \%$ SCC, $100 \%$ CIS, $77.8 \%$ severe dysplasia, $65.1 \%$ moderate dysplasia and $33.3 \%$ mild dysplasia cases were positively stained by the DNA-instability test diffusely or sporadically, indicating their malignancy (Figure le). Reflecting the malignant character, these cases showed a remarkable increase in the PCNA-index with the loss of polarity of PCNA-positive cell distribution and also increase in number, mean and largest sizes and maximum shape-irregularity of AgNORs dots, especially in the areas of positive DNA-instability test. The frequency of chromosome 17 polysomies, and the percentage of hyperdiploid cells measured by means of the chromosome index using interphase cytogenetics, and p53, and bcl-2-protein (a protein to extend cell survival by protecting the cell against apoptosis without affecting cell proliferation) (Bakhshi et al., 1985; Hockenbery et al., 1990) immunostaining positivities, were also found to be significantly increased in moderate and severe dysplasia and in cancer cases in comparison to normal and mild dysplasia cases as a whole; but the values showed no apparent statistical differences when counted exclusively in the areas with positive DNA-instability testing, irrespective of the dysplasia grade. This indicates that there is no differences between dysplasia and cancer lesions, where DNA-instability 
testing shows positive staining. All these data clearly show that the clones with positive DNA-instability testing in the dysplasia can be again regarded as procancer clones with the functional atypia of enhanced potency of cell proliferation and protected survival capability, but without sufficient morphological atypia to make cancer diagnosis valid.

\section{Detection of procancer clones in oral leukoplakia (Iwasa et al., 2001)}

Oral leukoplakia is regarded as a precancerous or potentially malignant lesion (Kramer et al., 1978), and is defined as a predominantly white lesion of the oral mucosa that cannot be characterized as any other definable lesion (Axéll et al., 1996), and histopathological grade of dysplasia is thought to be the most important indicator of the malignant potential of leukoplakia (Burkhardt et al., 1985). The diagnosis of epithelial dysplasia, however, requires a considerable experience (Pindborg et al., 1985), and interobserver agreement rates are generally poor, ranging between $49 \%$ and $69 \%$ (Karabulut et al., 1995). The frequency of oral carcinoma in patients with oral leukoplakia ranges from $2.4 \%$ to $70.3 \%$ during a $6-20$ year observation period (Einhorn and Wersäll, 1967; Silverman et al., 1984; Hansen et al., 1985; Silverman and Grosky, 1997; Schepman et al., 1998; Lee et al., 2000). Furthermore, Lee et al. (2000) reported that the cancer risk of oral leukoplakia with moderate to severe dysplasia was 2.3 times higher than that with hyperplasia or mild dysplasia. However, malignancy could also develop in non-dysplastic lesions such as hyperplasia (Silverman et al., 1984; Hansen et al., 1985; Murti et al., 1998; Schepman et al., 1998).

The DNA-instability test was applied to tissues of oral leukoplakia cases histopathologically assessed as hyperplasia, mild, moderate, and severe dysplasia, and invasive squamous cell carcinoma (SCC). The tissues were also subjected to immunohistochemical staining for p53, DFF45, VEGF, and analysis of AgNORs parameters. The DNA-instability test was positive in $100 \%$ SCC, $100 \%$ severe dysplasia, $72.7 \%$ moderate dysplasia, 50.0\% mild dysplasia, and $23.7 \%$ hyperplasia cases, indicating their malignancy (Figure 1f). The proportion of lesions positive for PCNA, p53, DFF45, VEGF, and values of AgNORs parameters steadily increased from hyperplasia to mild, moderate, and severe dysplasia, and SCC, especially in those showing positive DNA-instability testing, also indicating their malignancy. But the percent numbers of the immunohistochemically-positive cells, and the mean values of AgNORs parameters in the areas with positive DNA-instability testing were not statistically changed in all lesions, showing no difference of them among the different stages of cancer progression, from hyperplasia to SCC where DNAinstability testing was positive. Furthermore, the proportion of PCNA-positive vascular endothelial cells in the vicinity of VEGF-positive epithelial lesion was significantly higher than that of negative DNA-instability testing, as revealed by triple immunohistochemical staining for VEGF, CD34 (a protein specific for vascular endothelial cells), and PCNA. Based on these results, $44.9 \%$ of oral leukoplakia were found to already contain procancer clones.

\section{Detection of procancer clones in otorhinolaryn- geal borderline neoplastic lesions (Tsuzuki et al., 1994)}

Laryngeal leukoplakia is regarded as a precancerous mucosal change with great similarity to oral leukoplakia, and its malignant transformation rate varies from $1 \%$ to $40 \%$ (Bouquot and Gnepp, 1991). The inverted papilloma is a locally aggressive sinonasal tumor that has a high rate of recurrence, simultaneous and subsequent development of malignancy, and tendency to multicentricity. The reported incidence of malignancy ranges from less than $2 \%$ to $53 \%$ (Lawson et al., 1989). Despite the high association rate of malignancy, the inverted papilloma is not necessarily regarded as precancerous (Woodson et al., 1985; Segal et al., 1986; Weissler et al., 1986).

Pleomorphic adenoma (mixed tumor) is the most common neoplasm of the parotid gland and classified originally as benign (Batsakis, 1979), but the same author (Batsakis, 1982) defined malignant mixed tumor which exists in three clinical and histological forms, as carcinosarcoma (Batsakis, 1979), metastasizing mixed tumor (Chen, 1978), and carcinoma in mixed tumor (Moberger and Eneroth, 1968). Additional cases of carcinosarcoma (Tortoledo et al., 1984; Talmi et al., 1990; Cherian et al., 1992), metastasizing mixed tumor (Freeman et al., 1990; Sim et al., 1990; Pitman et al., 1992), and carcinoma in mixed tumor (Tortoledo et al., 1984) were further reported. The frequency of carcinosarcoma, and carcinoma in mixed tumor, was reported to be $0.2 \%$ (Tortoledo 
et al., 1984), and 2.1\% (Moberger and Eneroth, 1968), respectively. Moberger and Eneroth (1968) further reported that distant metastases were present in $28.1 \%$ of all carcinoma in mixed tumor cases, but that no pleomorphic structures were demonstrable in the metastatic lesions. They further pointed out the difficulty of evaluating cellular atypia as a marker of malignancy in pleomorphic adenoma, and also that the lack of sharp delimitation and absence of a capsule may give a false impression of infiltration.

DNA-instability test was applied to the borderline malignancy cases, laryngeal leukoplakia, nasal inverted papilloma, and salivary gland pleomorphic adenoma cases, as well as to normal and SCC cases. The results showed that 100\% SCC, $90.1 \%$ leukoplakia, 100\% inverted papilloma, and 63.6\% pleomorphic adenoma cases were positively stained by the DNA-instability test, diffusely or sporadical-

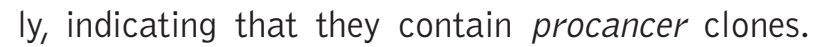
Reflecting the malignant character, these cases showed a remarkable increase in the PCNA-index with loss of polarity of PCNA-positive cell distribution, and also increased number, mean and largest sizes, and maximum shape irregularity of AgNORs, especially in the procancer clones with positive DNA-instability test.

These results indicate that all nasal inverted papillomas are malignant in nature, namely in situ carcinoma, and the majority of leukoplakia is also regarded as in situ carcinoma, although a certain percentage of simple hyperplasia may be also included among the in situ carcinoma. Furthermore, the pleomorphic adenoma of salivary glands is regarded as unstable tumor which often contains or predisposes to bear malignant subclones with occasional capsular or extra-capsular invasion, reflecting the progression of malignancy. Reflecting this (Steinbeck, 2001), abnormal mitoses were sometimes encountered among the clones in pleomorphic adenoma positively stained with DNA-instability testing. These cancer clones should be again referred to as procancer showing functional atypia with positive DNA-instability testing and abnormal expression of other cancer markers, but showing no sufficient morphological atypia.

\section{Detection of cancer clones in bone giant cell tumor (BGCT) (Azuchi et al., 1998)}

BGCT is one of the most difficult tumors to prospect the biological behavior merely on the basis of histological characteristics. Jaffe et al. (1940) regarded the smaller mononucleated fusiform or polyhedral stromal cells as the main component of the tumor rather than the multinucleated giant cells resembling osteoclasts, and classified BGCT into 3 histological gradings. They attempted to correlate the histological gradings of tumors with their prognosis. Willis (1949), and Russell (1949) were opposed to this concept that the tumor shows a range of structures and behaviors, and a few, initially indistinguishable from their benign fellows, invade and metastasize, without departing greatly from the structure of tumors of benign behavior. Williams et al., (1954) denied the significance of the normal mitotic counts proposed by King (1932) and the histological grading proposed by Jaffe et al. (1940) in evaluating the behavior of BGCT, stating that potentially aggressive or malignant BGCT are not initially distinguishable histologically as such.

Campannacci et al. (1975) used radiographic criteria for grading BGCT, and Tehranzadeh et al., (1989) appreciated the radiographic grading as critically important in planning the management of this tumor, but many other authors concluded that radiological assessment of BGCT is of limited and uncertain value in indicating prognosis. On the other hand, computed tomography (CT) is more powerful in determining thin cortical shells or invasion of the cortex by BGCT (Tehranzadeh et al., 1989), and Hudson et al. (1984) regarded CT as providing the most useful and complete evaluation of the exact extent of BGCT invasions which is essential to secure adequate surgical margins and prevent recurrence, especially when there is cortical penetration with invasions of soft tissue or joint cavities. So the histological and clinical criteria for malignancy of BGCT are quite ambiguous and controversial.

The DNA-instability test was applied to benign (osteochondroma, enchondroma), borderline (BGCT), and malignant (chondrosarcoma and osteosarcoma) mesenchymal tumors. As the results showed, $82.6 \%$ BGCT, and $100 \%$ malignant mesenchymal tumors were positive to the DNA-instability test, indicating their malignancy. All benign tumors were completely negative to DNA-instability testing. Reflecting the malignant character, all the DNA-instability test-positive malignant- and BGCT cases showed statistically higher values of the PCNA-index, and all the AgNORs parameters 
in comparison to those of the benign mesenchymal tumor cases. C-myc immunohistochemistry was positive for $66.7 \%$ malignant cases, and $26.3 \%$ BGCT cases were positive to DNA-instability testing, especially in the areas with positive DNA-instability testing.

All BGCT cases negative to DNA-instability testing were also negative for $\mathrm{c}-\mathrm{myc}$ expression. Among the BGCT cases positive to the DNA-instability test, $94.7 \%$ showed cortical bone destruction and $26.3 \%$ showed extra-osseous expansion or invasion, as revealed by CT. No such radiographic changes were detected in the BGCT cases negative to the DNA-instability test.

Furthermore, only stromal cells were positively stained in the BGCT cases that were positively stained with the DNA-instability test, and all giant cells were completely negative, indicating that the concept of Jaffe et al., (1940) seems to be true (Figure 1g). In such cases, abnormal mitoses (Steinbeck, 2001) were sometimes encountered among the stromal cells positive with DNA-instability testing, reflecting their malignancy. These results clearly show that the majority of BGCT are malignant, and the DNA-instability test and detection of the cortical bone destruction by $\mathrm{CT}$ may be regarded as the reliable histological and clinical markers, respectively, for distinguishing benign and malignant BGCT cases.

\section{Preserved normal basal cell layer in Bowen' dis- ease (Ishida et al., 2001)}

Bowen's disease is an intraepithelial squamous cell carcinoma with potential progression to invasive squamous cell carcinoma (Sober and Burstein, 1995; Kirkham, 1997; Mackie, 1998). The percentage of cases with Bowen's disease that progress to invasive squamous cell carcinoma is $4 \%$ (ThestrupPedersen et al., 1988) to 5\% (Graham and Helwig, 1973), and 8\% (Glogau, 2000), respectively. Bowen's disease occurs mainly in sun-exposed skin areas (Thestrup-Pedersen et al., 1988; Kossard and Rosen, 1992) and is possibly caused by ultraviolet light (Reizner et al., 1994; Chuang et al., 1995), or on the lower extremities (Cox, 1994). A number of studies have demonstrated relatively high incidence of human papilloma virus (HPV) in Bowen's disease affecting the genital region (38$80 \%)$ and other skin regions ( $19.4-40 \%)$, by using Southern blot analysis with HPVI6 DNA (Ikenberg et al., 1983), immunohistochemical staining for viral antigens (Grussendorf-Conen and Giesen, 1990), and in situ hybridization (ISH) (Kettler et al., 1990). Bowen's disease is also an important complication of chronic hyperarsenism (Yeh et al., 1968; Miki et al., 1982). Histologically highly atypical cancer cells with clumping lie in complete disorder throughout the entire epidermal thickness (Kirkham, 1997). The basal layer in Bowen's disease may, however, appear free of dysplasia. Basal and suprabasal cells in Bowen's disease appear almost normal on electron microscopy, except that the tonifilaments in these cells slightly aggregate in a fascicular form (Seije and Mizuno, 1969). Immunohistochemically, the basal cells are either weakly positive or completely negative for the expression of PCNA (Geary and Cooper, 1992; Takata and Matsui, 1994; Li and Lee, 1996), although the PCNA-index is generally high in other cell layers in Bowen's disease (Tsuji et al., 1992). DNA-instability testing was applied to Bowen's disease, squamous cell carcinoma (SCC), and seborrheic keratosis lesions. As the results showed, $100 \%$ Bowen's disease and $100 \%$ SCC cases were positive, but all seborrheic keratosis cases were completely negative. In Bowen's disease, all basal cells were completely negative to DNA-instability testing, although all cancer cells in upper layers were strongly positive diffusely (Figure $1 \mathrm{~h}$ ). They were also negative to p53 immunohistochemistry showing normal signals of chromosome 17 as revealed by interphase ISH with only a slightly enhanced PCNA-index, in sharp contrast to marked abnormalities of these cancer markers in all upper cell layers. Immunohistochemical staining with 34 $\beta$-E12 (monoclonal antibody against cytokeratins 1, 5, 10, and 14, which stains all normal epidermal keratinocytes including basal cells) showed that only basal cells of Bowen's disease stained strongly and homogeneously, while all cancer cells in upper layers of Bowen's disease were only sporadically stained.

These results clearly show that the basal cells in Bowen's disease are normal in nature.

\section{Conclusions}

The newly developed DNA-instability testing demonstrated that a majority of so called borderline malignancies, such as gastric adenoma, colorectal adenoma. Uterine cervical dysplasia, oral and laryngeal leukoplakia, nasal inverted papillo- 
ma, salivary gland pleomorphic adenoma, and bone giant cell tumor, often contain cancer clones, and they should be dealt with as such to prevent further progression and recurrence by removing them as completely as possible.

It also revealed that multinucleated giant cells in bone giant cell tumor and basal cells in Bowen's disease are non-malignant or normal.

\section{References}

Arden KC, Pathak S, Frankel LS, Zander A. Ag-NOR staining in human chromosomes: differential staining in normal and leukemic bonemarrow samples. Int J Cancer 1985;36:647-9.

Axéll T, Pindborg JJ, Smith CJ, van der Waal I. Oral white lesions with special reference to precancerous and tobacco-related lesions. J Oral Pathol Med 1996;25:49-54.

Ayres JG, Crocker JG, Skilbeck NQ. Differentiation of malignant from normal and reactive mesothelial cells by the argyrophile technique for nucleolar organiser region associated proteins. Thorax 1988;43:366-70.

Azuchi M, Baba H, Imura S, Noriki S, Imamura $Y$, Fukuda M. Demonstration of biological aggressiveness of bone giant cell tumor by the comparative study of immunohistochemical detection of DNA-instability and cortical bone destruction by CT. Acta. Histochem. Cytochem 1998;31:401-10.

Bakhshi A, Jensen JP, Goldman P, Wright JJ, McBride OW, Epstein $A L$, et al. Cloning the chromosomal breakpoint of $t(14 ; 18)$ human lymphomas: clustering around $\mathrm{JH}$ on chromosome 14 and near a transcriptional unit on 18.Cell 1985;41:899-906.

Barr FG. Translocations, cancer and the puzzle of specificity. Nat Genet 1998;19:121-4.

Batsakis JG. Tumors of the major salivary gland. In: Tumors of the Head and Neck: Clinical and pathological considerations. 2nd ed. Baltimore: Williams and Wilkins; p.22,1979.

Batsakis JG. Malignant mixed tumor. Ann Otol Rhinol Laryngol 1982;91:342-3.

Böhm N, Seibert Hu. Zur Bestimmung der Parameter der BatemanFunktion bei der Auswertumg von Feulgen-Hydrolysenkurven. Histochemie 1966;6:260-6.

Bouquot JE, Gnepp DR. Laryngeal precancer: a review of the literature, commentary, and comparison with oral leukoplakia. Head Neck 1991;13:488-97.

Bravo R, Frank R, Blundell PA, Macdonald-Bravo H. Cyclin/PCNA is the auxiliary protein of DNA polymerase-\%. Nature $1987 ; 326: 515-7$

Burkhardt A. Advanced methods in the evaluation of premalignant lesions and carcinomas of the oral mucosa. J Oral Pathol $1985 ; 14: 751-78$

Cahill DP, Lengauer C, Yu J, Riggins GJ, Willson JK, Markowitz SD, et al. Mutations of mitotic checkpoint genes in human cancers. Nature 1998; 392:300-3.

Cahill DP, da Costa LT, Carson-Walter EB, Kinzler KW, Vogelstein B, Lengauer $C$. Characterization of MAD2B and other mitotic spindle checkpoint genes. Genomics 1999;58:181-7.

Campannacci, M, Giunti, A, and OImi, R. Giant cell tumors of bone: A study of 209 cases with long-term follow-up in 130. Ital. J. Orthop. Traumatol. 1975;1:249-277.

Chen C and Kolodner RD. Gross chromosomal rearrangements in Saccharomyces cerevisiae replication and recombination defective mutants. Nat Genet 1999;23:81-5.

Chen KT. Metastasizing pleomorphic adenoma of the salivary gland. Cancer 1978;42:2407-11.

Cherian T, Sebastian P, Abraham EK, Ahmed IM, Jayakumar KL, Sivaramakrishnan P. Unusual multiple metastases from malignant pleomorphic adenoma of the parotid gland. J Laryngol Otol $1992 ; 106: 652-5$
Choo KH. Domain organization at the centromere and neocentromere.Dev Cell 2001;1:165-77.

Chuang TY, Reizner GT, Elpern DJ, Stone JL, Farmer ER. Nonmelanoma skin cancer in Japanese ethnic Hawaiians in Kauai, Hawaii: an incidence report. J Am Acad Dermatol 1995;33:422-6.

Cordonnier AM, Fuchs RP. Replication of damaged DNA: molecular defect in xeroderma pigmentosum variant cells. Mutat Res 1999;435:111-9.

Correa P. Human gastric carcinogenesis: a multistep and multifactorial process--First American Cancer Society Award Lecture on Cancer Epidemiology and Prevention. Cancer Res 1992;52:673540.

Cox NH. Body site distribution of Bowen's disease. $\mathrm{Br} J$ Dermatol 1994;130:714-6.

Crocker J, Nar P. Nucleolar organizer regions in lymphomas. J Pathol 1987;151:111-8.

Darzynkiewicz Z, Traganos F, Andreeff M, Sharpless T, Melamed MR. Different sensitivity of chromatin to acid denaturation in quiescent and cycling cells as revealed by flow cytometry. J Histochem Cytochem 1979;27:478-85.

Dean RT. A mechanism for accelerated degradation of intracellular proteins after limited damage by free radicals. FEBS Lett 1987;220:278-82.

Dervan PA, Gilmartin LG, Loftus BM, Carney DN. Breast carcinoma kinetics. Argyrophilic nucleolar organizer region counts correlate with Ki67 scores. Am J Clin Pathol 1989;92:401-7.

Di Gregorio C, Morandi P, Fante R, De Gaetani C. Gastric dysplasia. A follow-up study. Am J Gastroenterol 1993;88:1714-9.

Doxsey S. The centrosome--a tiny organelle with big potential. Nat Genet 1998;20:104-6.

Duijndam WAL, Duijn P van. The influence of chromatin compactness on the stoichiometry of the Feulgen-Schiff procedure studied in model films. II. Investigations on films containing condended or swollen chicken erythrocyte nuclei. J Histochem Cytochen 1975;23:891-900.

Einhorn J, Wersäll J. Incidence of oral carcinoma in patients with leukoplakia of the oral mucosa. Cancer 1967;20:2189-93.

Elledge SJ. Cell cycle checkpoints: preventing an identity crisis. Science 1996;274:1664-72.

Enari M, Sakahira H, Yokoyama H, Okawa K, Iwamatsu A, Nagata S. A caspase-activated DNase that degrades DNA during apoptosis, and its inhibitor ICAD. Nature 1998;391:43-50.

Farinati F, Cardin F, Di Mario F, Valiante F, Naccarato R, ArslanPagnini $C$, et al. Follow-up in gastric dysplasia patients. Am J Surg Pathol 1989;13:173-4.

Farinati $F$, Rugge $M$, Valiante $F$, Baffa $R$, Di Mario $F$, Naccarato $R$. Gastric epithelial dysplasia. Gut 1991;32:457.

Fenoglio-preiser C, Carneiro $F_{\text {, Correa }} \mathrm{P}_{\text {, Guilford }} \mathrm{P}_{\text {, Lambert }} \mathrm{R}_{d}$ Megraud $F$, et al. Gastric carcinoma. In World Health Organization Classification of Tumours Pathology and Genetics of Tumours of the Digestive System. Hamilton SR and Aaltonen LA, Eds. IARC Press: Lyon; 2000.p.37-68.

Ferguson AT, Evron E, Umbricht CB, Pandita TK, Chan TA, Hermeking $\mathrm{H}$, et al. High frequency of hypermethylation at the 14-3-3 sigma locus leads to gene silencing in breast cancer. Proc Natl Acad Sci USA 2000;97: 6049-54.

Fertitta AM, Comin U, Terruzzi V, Minoli G, Zambelli A, Cannatelli G, et al. Clinical significance of gastric dysplasia: a multicenter followup study. Gastrointestinal Endoscopic Pathology Study Group. Endoscopy 1993; 25: 265-8.

Finlay CA, Hinds $\mathrm{PW}$, Tan $\mathrm{TH}$, Eliyahu $\mathrm{D}$, Oren $\mathrm{M}$, Levine AJ. Activating mutations for transformation by 053 produce a gene product that forms an hsc70-p53 complex with an altered half-life. Mol Cell Biol 1988;8:531-9.

Folkman J, Klagsbrun M. Angiogenic factors. Science 1987 23;235:442-7.

Freeman SB, Kennedy KS, Parker GS, Tatum SA. Metastasizing pleomorphic adenoma of the nasal septum. Arch Otolaryngol Head Neck Surg 1990;116:1331-3.

Friedberg EC, Gerlach VL. Novel DNA polymerases offer clues to the molecular basis of mutagenesis. Cell 1999;98:413-6.

Fujita S. Biology of early gastric carcinoma. Pathol Res Pract 1978; 163:297-309.

Fukasawa K, Choi T, Kuriyama R, Rulong S, Vande Woude GF. 
Abnormal centrosome amplification in the absence of p53. Science $1996 ; 271: 1744-7$

Fukuda M, Miyoshi N, Nakanishi K. Quantitative analysis of DNA damage. In: Japan Soc Histochem Cytochem (ed) Histochemistry and Cytochemistry. 1985; Vol19. Gakusai Kikaku, Tokyou, pp 10121.

Fukuda M, Miyoshi N, Hattori T, Sugihara H, Hosokawa Y, Nakanishi K. Different instability of nuclear DNA at acid hydrolysis in cancerous and noncancerous cells as revealed by fluorescent staining with acridine orange. Histochemistry 1986;84:556-60.

Fukuda M, Noriki S, Imamura Y, Miyoshi N, Kimura S, Koizumi K,Suzuki K,Sakurai H,Sakaguchi R. Differential immunohistochemical staining of cancerous cells with anti-single-stranded DNA antiserum in ordinary pathological paraffin section after DNAdenaturation by acid hydrolysis. Eur J Histochem 1993;37:309-19.

Gauwerky CE, Croce CM. Chromosomal translocations in leukaemia. Semin Cancer Biol 1993;4:333-40.

Geary WA, Cooper PH. Proliferating cell nuclear antigen (PCNA) in common epidermal lesions. An immunohistochemical study of proliferating cell populations. J Cutan Pathol 1992;19:458-68.

Glogau RG. The risk of progression to invasive disease. J Am Acad Dermatol 2000;42:23-4.

Goldstein NS, Lewin KJ. Gastric epithelial dysplasia and adenoma: historical review and histological criteria for grading. Hum Pathol 1997;28:127-33.

Goodpasture C, Bloom SE. Visualization of nucleolar organizer regions in mammalian chromosomes using silver staining. Chromosoma 1975;53:37-50.

Goshima G, Kiyomitsu T, Yoda K, Yanagida M. Human centromere chromatin protein hMis12, essential for equal segregation, is independent of CENP-A loading pathway. J Cell Biol 2003;160:25-39.

Graham JH, Helwig EB. Erythroplasia of Queyrat. A clinicopathologic and histochemical study. Cancer 1973;32:1396-414.

Grussendorf-Conen EI, Giesen M. Papillomavirus common antigen in Bowen's disease. Dermatologica 1990;181:11-5.

Hansen LS, Olson JA, Silverman S Jr. Proliferative verrucous leukoplakia. A long-term study of thirty patients.Oral Surg Oral Med Oral Pathol 1985;60:285-98.

Hartwell LH, Smith D. Altered fidelity of mitotic chromosome transmission in cell cycle mutants of $S$. cerevisiae. Genetics 1985;110:381-95.

Hartwell L. Defects in a cell cycle checkpoint may be responsible for the genomic instability of cancer cells. Cell 1992;71:543-6.

Hatchoh M, Ueda K, Imamura Y, Noriki S, Fukuda M. Qualitative and quantitative changes in nuclear DNA and phenotypic gene expression in human malignant skin tumors during their progression. Eur $\mathrm{J}$ Histochem 1992;36:289-302.

Hirai K., Kumakiri M., Ueda K., Imamura Y., Noriki S., Nishi Y., Kato $\mathrm{H}$., and Fukuda M.: Clonal evolution and progression of 20-methylcholanthrene-induced squamous cell carcinoma of mouse epidermis as revealed by DNA instability and other malignancy markers. Eur $\mathrm{J}$ Histochem 45, 319-332, 2001.

Hockenbery D, Nunez G, Milliman C, Schreiber RD, Korsmeyer SJ. $\mathrm{Bcl}-2$ is an inner mitochondrial membrane protein that blocks programmed cell death. Nature 1990;348:334-6.

Hollstein M, Sidransky D, Vogelstein B, Harris CC. p53 mutations in human cancers. Science 1991;253:49-53.

Howell WM, Denton TE, Diamond JR. Differential staining of the satellite regions of human acrocentric chromosomes. Experientia 1975;31:260-2.

Hudson TM, Schiebler M, Springfield DS, Enneking WF, Hawkins IF Jr, Spanier SS. Radiology of giant cell tumors of bone: computed tomography, arthro-tomography, and scintigraphy. Skeletal Radiol 1984; 11:85-95.

Ikenberg H, Gissmann L, Gross G, Grussendorf-Conen EI, zur Hausen $H$. Human papillomavirus type-16-related DNA in genital Bowen's disease and in Bowenoid papulosis. Int J Cancer 1983;32:563-5.

Iwasa M, Imamura $Y$, Noriki $S$, Nishi $Y$, Kato $H$, Fukuda M. Immunohistochemical detection of early-stage carcinogenesis of oral leukoplakia by increased DNA-instability and various malignancy markers. Eur J Histochem 2001;45:333-46.

Jaskulski D, deRiel JK, Mercer WE, Calabretta B, Baserga R. Inhibition of cellular proliferation by antisense oligodeoxynucleotides to PCNA cyclin. Science 1988;240:1544-6.
Jaffe H.L., Lichtenstin, L and Portis, R.B.: Giant cell tumor of bone: Its pathologic appearance, grading supposed variants and treatment. Arch. Pathol 1940;30:993-1031.

Jin DY, Spencer F, Jeang KT. Human T cell leukemia virus type 1 oncoprotein Tax targets the human mitotic checkpoint protein MADI. Cell 1998;93:81-91.

Johnson RE, Prakash S, Prakash L. Efficient bypass of a thyminethymine dimer by yeast DNA polymerase, Poleta. Science 1999;283:1001-4.

Jones PA. DNA methylation errors and cancer. Cancer Res 1996;56:2463-7.

Jones PA, Gonzalgo ML. Altered DNA methylation and genome instability: a new pathway to cancer. Proc Natl Acad Sci U S A 1997; $94: 2103-5$.

Karabulut A, Reibel J, Therkildsen MH, Praetorius F, Nielsen HW Dabelsteen E. Observer variability in the histologic assessment of oral premalignant lesions. J Oral Pathol Med 1995;24:198-200.

Kasai H, Nishimura S. Hydroxylation of guanine in nucleosides and DNA at the C-8 position by heated glucose and oxygen radical-forming agents.?Environ Health Perspect. 1986;67:111-6.

Kettler AH, Rutledge M, Tschen JA, Buffone G. Detection of human papillomavirus in nongenital Bowen's disease by in situ DNA hybridization. Arch Dermatol 1990;126:777-81.

Khaled A, Imamura Y, Noriki S, Fukuda M. Early progression stage of malignancy of uterine cervical dysplasia as revealed by immunohistochemical demonstration of increased DNA-instability.?Eur J Histochem 2000;44:143-56.

Kikuchi T, Toyota M, Itoh F, Suzuki H, Obata T, Yamamoto $H$,et al Inactivation of p57KIP2 by regional promoter hypermethylation and histone deacetylation in human tumors. Oncogene 2002;21:2741-9.

King, E.S.J., Malignant giant cell tumour of bone. Brit. J. Surg 1932;20:269-278

Kirkham N.:Tumors and cysts of the epidermis In: Lever's histopathology of the skin, 8th edn. (Eds. Elder D., Elenitsas R., Jaworsky C., and Johnson B.), Lippincott-Raven, Philadelphia, pp.685-746,1997

Kossard S, Rosen R. Cutaneous Bowen's disease. An analysis of 1001 cases according to age, sex, and site. J Am Acad Dermatol 1992;27:406-10.

Kramer IR, Lucas RB, Pindborg JJ, Sobin LH. Definition of leukoplakia and related lesions: an aid to studies on oral precancer. Oral Surg Oral Med Oral Pathol 1978;46:518-39.

Kunkel TA. Nucleotide repeats. Slippery DNA and diseases. Nature 1993;365:207-8.

Lane D. Awakening angels. Nature 1998;394:616-7.

Lansdown M, Quirke P, Dixon MF, Axon AT, Johnston D. High grade dysplasia of the gastric mucosa: a marker for gastric carcinoma. Gut 1990;31:977-83.

Lawson W, Le Benger J, Som P, Bernard PJ, Biller HF. Inverted papilloma: an analysis of 87 cases. Laryngoscope 1989;99:1117-24.

Lee JJ, Hong WK, Hittelman WN, Mao L, Lotan R, Shin DM,et al. Predicting cancer development in oral leukoplakia: ten years of translational research. Clin Cancer Res 2000;6:1702-10.

Lengauer C, Kenneth W, Vogelstein B, Genetic instability in human cancers. Nature 1998;396:643-9

Leung DW, Cachianes G, Kuang WJ, Goeddel DV, Ferrara N. Vascular endothelial growth factor is a secreted angiogenic mitogen. Science 1989;246:1306-9.

Levine RL, Oliver CN, Fulks RM, Stadtman ER. Turnover of bacterial glutamine synthetase: oxidative inactivation precedes proteolysis. Proc Natl Acad Sci U S A 1981;78:2120-4.

Levinson $G$, Gutman GA. High frequencies of short frameshifts in polyCA/TG tandem repeats borne by bacteriophage M13 in Escherichia coli K-12. Nucleic Acids Res 1987;15:5323-38.

Li J, Lee YS. Proliferating cell nuclear antigen (PCNA) expression in pseudoepitheliomatous hyperplasia, keratoacanthoma and squamous cell carcinoma of the skin. Ann Acad Med Singapore 1996;25:526-30.

Liu X, Zou H, Slaughter C, Wang X. DFF, a heterodimeric protein that functions downstream of caspase-3 to trigger DNA fragmentation during apoptosis. Cell 1997;89:175-84.

Mackie R.M.: Epidermal skin tumours. In: Rook/Wilkinson/Ebling textbook of dermatology, 6th edn.(Eds. Champion RH., Burton J.L., Burns D.A., and Breathnach S.M. Blackwell Science, 
Oxford,pp.1651-1693,1998.

Madokoro S, Urata Y, Hosokawa Y, Hattori T, Pellicciari C.Oki F, et al. Computer analysis of subparameters of depurination and depolymerization rate constant in Feulgen DNA hydrolysis. Basic Appl Histochem 1985;29:199-214.

Masutani C, Kusumoto R, Yamada A, Dohmae N, Yokoi M, Yuasa M, et al. The XPV (xeroderma pigmentosum variant) gene encodes human DNA polymerase eta. Nature 1999;399:700-4.

Masutani C, Kusumoto R, Iwai S, Hanaoka F. Mechanisms of accurate translesion synthesis by human DNA polymerase eta. EMBO J 2000; 19:3100-9.

Miki Y, Kawatsu T, Matsuda K, Machino H, Kubo K. Cutaneous and pulmonary cancers associated with Bowen's disease. J Am Acad Dermatol 1982;6:26-31.

Ming SC, Bajtai A, Correa P, Elster K, Jarvi OH, Munoz N,et al. Gastric dysplasia. Significance and pathologic criteria. Cancer 1984;54:1794-801.

Mitelman,F., Johansson,B.; Mertens, F. Catalog of chromosome Aberratons is Cancer Vol.2(Wiley Liss New Yok, 1994).

Mitelman F, Mertens F, Johansson B. A breakpoint map of recurrent chromosomal rearrangements in human neoplasia. Nat Genet 1997;15: 417-74.

Miyoshi N, Fukuda M. Quantitative detection of DNA damage in the neuronal cells of the cerebellum and cerebrum by the analysis of Feulgen hydrolysis curves. Histochemistry 1986;84:561-5.

Moberger JG, Eneroth CM. Malignant mixed tumors of the major salivary glands. Special reference to the histologic structure in metastases. Cancer 1968;21:1198-211.

Murray AW. The genetics of cell cycle checkpoints. Curr Opin Genet Dev 1995;5:5-11.

Murti PR, Warnakulasuriya KA, Johnson NW, Bhonsle RB, Gupta PC, Daftary DK, et al. p53 expression in oral precancer as a marker for malignant potential. J Oral Pathol Med 1998;27:191-6.

Muscara M, Giuffre G, Tuccari G, Barresi G. Nucleolar organizer regions in dysplastic and neoplastic lesions of the large bowel. Eur J Basic Appl Histochem 1991;35:401-8.

Nakamura K, Sakaguchi H, Enjoji M. Depressed adenoma of the stomach.?Cancer 1988;62:2197-202.

Nasmyth K. At the heart of the budding yeast cell cycle. Trends Genet. $1996 ; 12: 405-12$

Nitta Y, Suzuki K, Kohli Y, Fujiki N, Imamura Y, Noriki S, et al. Early progression stage of malignancy of human colon border-line adenoma as revealed by immunohistochemical demonstration of increased DNA-instability. Eur J Histochem 1993;37:207-18.

Noriki S, Imamura Y, Ikeda T, Nakanishi K, Miyoshi N, Kohno M, et al. Multi-organ damage (MOD) induced by cancer cachexia and its pathogenesis. Basic Appl Histochem 1989;33:337-46.

Nowell P. The clonal evolution of tumor cell populations. Science 1976;194:23-8.

Obuse C, Yang H, Nozaki N, Goto S, Okazaki T, Yoda K. Proteomics analysis of the centromere complex from HeLa interphase cells: UVdamaged DNA binding protein 1 (DDB-1) is a component of the CEN-complex, while BMI-1 is transiently co-localized with the centromeric region in interphase. Genes Cells 2004;9:105-20.

Ohmori H, Friedberg EC, Fuchs RP, Goodman MF, Hanaoka F, Hinkle $D$, et al. The Y-family of DNA polymerases. Mol Cell 2001;8:7-8.

Otaki T, Kohli Y, Fujiki N, Imamura Y, Fukuda M. Early progression stage of malignancy as revealed by immunohistochemical demonstration of DNA instability; I, Human gastric adenomas. Eur J Histochem 1994;38:281-90.

Otamiri T, Sjodahl R. Increased lipid peroxidation in malignant tissues of patients with colorectal cancer. Cancer. 1989;64:422-5.

Parsons R, Li GM, Longley MJ, Fang WH, Papadopoulos N, Jen J, et al. Hypermutability and mismatch repair deficiency in RER+ tumor cells. Cell 1993;75:1227-36.

Paulovich AG, Toczyski DP, Hartwell LH. When checkpoints fail. Cell 1997;88:315-21.

Peltomaki $\mathrm{P}$, de la Chapelle A. Mutations predisposing to hereditary nonpolyposis colorectal cancer. Adv Cancer Res 1997;71:93-119.

Peskin AV, Shlyahova L. Cell nuclei generate DNA-nicking superoxide radicals. FEBS Lett 1986;194:317-21.

Pindborg JJ, Reibel J, Holmstrup P. Subjectivity in evaluating oral epithelial dysplasia, carcinoma in situ and initial carcinoma. J Oral
Pathol 1985; 14:698-708.

Pitman MB, Thor AD, Goodman ML, Rosenberg AE. Benign metastasizing pleomorphic adenoma of salivary gland: diagnosis of bone lesions by fine-needle aspiration biopsy. Diagn Cytopathol 1992;8:384-7.

Pöppe C, Pellicciari C, Bachmann K. Computer analysis of Fuelgen hydrosysis kinetics. Histochemistry 1979;60:53-60

Rotman G, Shiloh Y. ATM: from gene to function. Hum Mol Genet. 1998;7:1555-63.

Reeves BR, Casey G, Honeycombe JR, Smith S. Correlation of differentiation state and silver staining of nucleolar organizers in the promyelocytic leukemia cell line HL-60. Cancer Genet Cytogenet 1984; 13:159-66.

Reizner GT, Chuang TY, Elpern DJ, Stone JL, Farmer ER. Bowen's disease (squamous cell carcinoma in situ) in Kauai, Hawaii. A population-based incidence report. J Am Acad Dermatol 1994;31:596600.

Ross R. Angiogenesis. Successful growth of tumours. Nature 1989;339:16-7.

Rugge M, Farinati F, Di Mario F, Baffa R, Valiante F, Cardin F. Gastric epithelial dysplasia: a prospective multicenter follow-up study from the Interdisciplinary Group on Gastric Epithelial Dysplasia. Hum Pathol 1991;22:1002-8.

Rugge M, Farinati F, Baffa R, Sonego F, Di Mario F, Leandro G, et al. Gastric epithelial dysplasia in the natural history of gastric cancer: a multicenter prospective follow-up study. Interdisciplinary Group on Gastric Epithelial Dysplasia. Gastroenterology 1994;107:128896.

Russell, DS.: Malignant osteoclastoma. J. Bone Joint Surg. 1949; 31:281-290

Sabol SL, Li R, Lee TY, Abdul-Khalek R. Inhibition of apoptosis-associated DNA fragmentation activity in nonapoptotic cells: the role of DNA fragmentation factor-45 (DFF45/ICAD). Biochem Biophys Res Commun 1998;253:151-8.

Sasaki H, Suzuki T, Funaki N, Hoshi T, Iwabuchi M, Ohi R, et al. Immunohistochemistry of DNA fragmentation factor in human stomach and colon: its correlation to apoptosis. Anticancer Res 1999; 19:5277-82.

Santi DV, Garrett CE, Barr PJ. On the mechanism of inhibition of DNA-cytosine methyltransferases by cytosine analogs. Cell 1983;33:9-10.

Saraga EP, Gardiol D, Costa J. Gastric dysplasia. A histological followup study. Am J Surg Pathol 1987;11:788-96.

Satoh A, Toyota M, Itoh F, Sasaki Y, Suzuki H, Ogi K, et al. Epigenetic inactivation of CHFR and sensitivity to microtubule inhibitors in gastric cancer. Cancer Res 2003;63:8606-13.

Schepman KP, van der Meij EH, Smeele LE, van der Waal I. Malignant transformation of oral leukoplakia: a follow-up study of a hospitalbased population of 166 patients with oral leukoplakia from The Netherlands. Oral Oncol 1998;34:270-5.

Schlüter C, Duchrow M, Wohlenberg C, Becker M H, Key G, Flad HD, et al. The cell proliferation-associated antigen of antibody Ki-67: a very large, ubiquitous nuclear protein with numerous repeated elements, representing a new kind of cell cycle-maintaining proteins. $J$ Cell Biol 1993;123:513-22.

Schueler MG, Higgins AW, Rudd MK, Gustashaw K, Willard HF. Genomic and genetic definition of a functional human centromere. Science. 2001;294:109-15.

Segal K, Atar E, Mor C, Har-EI G, Sidi J. Inverting papilloma of the nose and paranasal sinuses. Laryngoscope 1986;96:394-8.

Seiji M, Mizuno F. Electron microscopic study of Bowen's disease. Arch Dermatol 1969;99:3-16.

Shen CY, Yu JC, Lo YL, Kuo CH, Yue CT, Jou YS, et al. Genome-wide search for loss of heterozygosity using laser capture microdissected tissue of breast carcinoma: an implication for mutator phenotype and breast cancer pathogenesis.Cancer Res 2000;60:3884-92.

Shikano T, Arioka $H$, Kobayashi R, Naito $H$, Ishikawa $Y$. Jumping translocations of $1 q$ in Burkitt lymphoma and acute nonlymphocytic leukemia.?Cancer Genet Cytogenet 1993;71:22-6.

Silverman S Jr, Gorsky M, Lozada F. Oral leukoplakia and malignant transformation. A follow-up study of 257 patients. Cancer 1984;53:563-8.

Silverman S Jr, Gorsky M. Proliferative verrucous leukoplakia: a follow-up study of 54 cases. Oral Surg Oral Med Oral Pathol Oral 
Radiol Endod 1997;84:154-7.

Sim DW, Maran AG, Harris D. Metastatic salivary pleomorphic adenoma. J Laryngol Otol 1990;104:45-7.

Sober AJ, Burstein JM. Precursors to skin cancer.Cancer 1995;75:645-50.

Steinbeck RG. Pathologic mitoses and pathology of mitosis in tumorigenesis. Eur J Histochem 2001;45:311-8.

Sun A, Noriki S, Imamura Y, Fukuda M. Detection of cancer clones in human gastric adenoma by increased DNA-instability and other biomarkers. Eur J Histochem 2003;47:111-22.

Takata M, Matsui Y. Proliferating cell nuclear antigen (PCNA) and p53 protein expression in Bowen's disease. J Dermatol 1994;21:947-52.

Talmi YP, Halpren M, Finkelstein $Y$, Gal R, Zohar Y. True malignant mixed tumour of the parotid gland. J Laryngol Otol 1990;104:3601.

Taylor SS, McKeon F. Kinetochore localization of murine Bubl is required for normal mitotic timing and checkpoint response to spindle damage. Cell 1997;89:727-35.

Tehranzadeh J, Murphy BJ, Mnaymneh W. Giant cell tumor of the proximal tibia: MR and CT appearance. J Comput Assist Tomogr 1989;13:282-6.

Thestrup-Pedersen K, Ravnborg L, Reymann F. Morbus Bowen. A description of the disease in 617 patients. Acta Derm Venereol 1988;68:236-9.

Thibodeau SN, Bren G, Schaid D. Microsatellite instability in cancer of the proximal colon. Science 1993;260:816-9

Tortoledo ME, Luna MA, Batsakis JG. Carcinomas ex pleomorphic adenoma and malignant mixed tumors. Histomorphologic indexes. Arch Otolaryngol 1984;110:172-6.

Tosi P, Baak JP, Luzi P, Miracco C, Lio R, Barbini P. Morphometric distinction of low- and high-grade dysplasias in gastric biopsies.? Hum Pathol 1989;20:839-44.

Toyota M, Sasaki $Y$, Satoh A, Ogi K, Kikuchi T, Suzuki $H$, et al. Epigenetic inactivation of CHFR in human tumors. Proc Natl Acad Sci U S A 2003; 100:7818-23.

Tsuji T, Shrestha P, Yamada K, Takagi H, Shinozaki F, Sasaki K, et al. Proliferating cell nuclear antigen in malignant and pre-malignant lesions of epithelial origin in the oral cavity and the skin: an immunohistochemical study. Virchows Arch A Pathol Anat Histopathol 1992; 420:377-83.

Tsujitani S, Furusawa M, Hayashi I. Morphological factors aid in therapeutic decisions concerning gastric adenomas. Hepatogastroenterology 1992;39:56-8.

Tsuzuki H, Saito H, Imamura Y, Noriki S, Fukuda M. Early progression stage of malignancy as revealed by immunohistochemical demonstration of DNA instability; II, Otorhinolaryngeal border-line neoplastic lesions. Eur J Histochem 1994;38:291-302.

Van Hemmen JJ, Meuling WJ. Inactivation of biologically active DNA by gamma-ray-induced superoxide radicals and their dismutation products singlet molecular oxygen and hydrogen peroxide.?Biochim Biophys Acta 1975;402:133-41.

Weissler MC, Montgomery WW, Turner PA, Montgomery SK, Joseph MP. Inverted papilloma. Ann Otol Rhinol Laryngol 1986:95:21521.

Williams RR, Dahlin DC, Ghormley RK. Giant-cell tumor of bone. Cancer 1954;7:764-73.

Willis, RA.: The pathology of osteoblatome or giant-cell tumour of bone. J Bone Joint Surg 1949;31:236-40.

Wong RL, Katz ME, Ogata K, Tan EM, Cohen S. Inhibition of nuclear DNA synthesis by an autoantibody to proliferating cell nuclear antigen/cyclin.?Cell Immunol 1987;110:443-8.

Wong DJ, Foster SA, Galloway DA, Reid BJ. Progressive region-specific de novo methylation of the $\mathrm{p} 16 \mathrm{CpG}$ island in primary human mammary epithelial cell strains during escape from $M(0)$ growth arrest. Mol Cell Biol 1999;19:5642-51.

Wood CB, Habib NA, Apostolov K, Thompson A, Barker W, Hershman $\mathrm{M}$, et al. Reduction in the stearic to oleic acid ratio in human malignant liver neoplasms. Eur J Surg Oncol 1985;11:347-8.

Woodgate R. A plethora of lesion-replicating DNA polymerases. Genes Dev 1999;13:2191-5.

Woodson GE, Robbins KT, Michaels L. Inverted papilloma. Considerations in treatment. Arch Otolaryngol 1985;111:806-11.
Xuan ZX, Ambe K, Enjoji M. Depressed adenoma of the stomach, revisited. histologic, histochemical, and immunohistochemical profiles. Cancer 1991;67:2382-9.

Yang L, Hashimura K, Qin C, Shrestha P, Sumitomo S, Mori M. Immunoreactivity of proliferating cell nuclear antigen in salivary gland tumours: an assessment of growth potential. Virchows Arch A Pathol Anat Histopathol 1993;422:481-6.

Yeh S, How SW, Lin CS. Arsenical cancer of skin. Histologic study with special reference to Bowen's disease. Cancer 1968;21:312-39.

Yin Y, Tainsky MA, Bischoff FZ, Strong LC, Wahl GM. Wild-type p53 restores cell cycle control and inhibits gene amplification in cells with mutant p53 alleles.Cell 1992;70:937-48.

Yu CC, Fletcher CD, Newman PL, Goodlad JR, Burton JC, Levison DA. A comparison of proliferating cell nuclear antigen (PCNA) immunostaining, nucleolar organizer region (AgNOR) staining, and histological grading in gastrointestinal stromal tumours. J Pathol 1992;166:147-52.

Zhang $H$, Tombline $G$, Weber BL. BRCA1, BRCA2, and DNA damage response: collision or collusion Cell 1998; 92:433-6. 
M. Fukuda et al. 